Arch. Tierz., Dummerstorf 49 (2006) 1, 77-88

University of Natural Resources and Applied Life Sciences Vienna (BOKU), Division Livestock Sciences, Vienna, Austria

ROSWITHA BAUMUNG, GERHARD LERCHER, ALFONS WILLAM
and JOHANN SÖLKNER

\title{
Feed Intake Behaviour of different Pig Breeds during Performance Testing on Station
}

\begin{abstract}
The aim of the study was to compare the feed intake behaviour of the two main pig breeds used as dam lines in Austria, Large White and Landrace, and to clarify whether there is an effect of MHS-type on feeding patterns in Pietrain. Feed intake behaviour of 1.593 pigs of three different breeds (618 Large White, 486 Landrace, 489 Pietrain) kept in group pens (maximum 13 pigs per pen) was analyzed. Different traits such as visits per hour and per day, time in the feeding station per hour and per day, feed intake per hour and per day and feed consumption rate were used to describe feed intake behaviour for the observation periods testing day and testing period. By using Generalized Linear Models differences in feed intake behaviour between the breeds were assessed. LSMeans were used to describe feed intake patterns for each breed. Large White and Landrace animals showed clearly different feed intake strategies: Large White can be characterized by a high number of visits in the station combined with shorter time spent in the station and lower consumption rates. Landrace animals tend to visit the feeding station less often per hour but compensate this with staying longer in the feeding station resulting in a higher feed intake per meal. The effects of MHS-type on feeding patterns of Pietrain, were small. Finally the relationships between selected growth and carcass traits (average daily gain, feed conversion ratio, lean meat content, meat quality index, intramuscular fat content) and selected feed intake behaviour traits (average feed intake per day, average time per day, average feed consumption rate) were analyzed using regression analysis. Average feed intake had a significant influence on all performance traits except the meat quality index.
\end{abstract}

Key Words: Feed intake behaviour, Growth traits, Carcass traits, Pig, Electronic feeding station

\section{Zusammenfassung}

Titel der Arbeit: Futteraufnahmeverhalten verschiedener Schweinerassen während der Leistungsprüfung auf Station

Ziel der vorliegenden Studie war der Vergleich des Futteraufnahmeverhaltens der beiden Schweinrassen Edelschwein und Landrasse, die in Österreich als wichtigste Sauenlinien eingesetzt werden, sowie die Untersuchung des Einflusses des MHS-Typs auf das Futteraufnahmeverhalten beim Pietrain. Daten über das Futteraufnahmeverhalten von 1,593 Schweinen (618 Edelschwein, 486 Landrasse, 489 Pietrain) aus Gruppenhaltung (maximal 13 Tiere pro Bucht) wurden analysiert. Zur Beschreibung des Futteraufnahmeverhaltens für den Beobachtungszeitraum Prüftag bzw. Prüfperiode (112 Tage) wurden die Merkmale Besuche in der Futterstation pro Stunde bzw. pro Tag, Zeit in der Futterstation pro Stunde bzw. pro Tag und Futteraufnahme pro Stunde bzw. pro Tag verwendet. Über Generalisierte Lineare Modelle wurde das Futteraufnahmeverhalten beschrieben. LSMittelwerte dienten der Beschreibung des Verhaltensmusters in den verschiedenen Rassen. Edelschwein und Landrasse zeigten deutlich unterschiedliche Futteraufnahmestrategien: Beim Edelschwein waren häufige Besuche in der Fütterungsstation mit kurzer Verweildauer und geringer Futterverzehrsrate charakteristisch. Landrassetiere tendieren zu weniger Besuchen mit höherer Verweildauer. Daraus resultierte insgesamt eine höhere Futteraufnahme pro Mahlzeit. Die Einflüsse des MHS-Typs auf das Futteraufnahmeverhalten waren gering. Mittels Regressionsanalysen wurde der Zusammenhang zwischen ausgewählten Mast- und Schlachtleistungsmerkmalen mit Merkmalen des Futteraufnahmeverhaltens untersucht. Die durchschnittliche Futteraufnahme zeigte einen signifikanten Einfluss auf Mast- und Schlachtleistungsmerkmale mit Ausnahme der Fleischqualitätskriterien.

Schlüsselwörter: Futteraufnahmeverhalten, Mastleistung, Schlachtleistung, Schwein, Elektronische Fütterungsstationen 
1. Introduction

The study of feeding behaviour has relevance to a number of scientific disciplines and an array of techniques has been developed for its measurement (YOUNG, 1993). Since the late 1980s electronic feeding stations are increasingly used in pig breeding (FELDE, 1996). Computerised feed intake recording systems have been developed to improve the accuracy of genetic selection. These allow to measure feeding behaviour of individuals fed in groups under ad libitum conditions at low cost per measurement (WEBB et al., 1990). Hence group housing and ad libitum feeding became more and more established on performance test stations in Europe (FELDE, 1996) leading to testing conditions closer to the housing systems on commercial farms.

Several researchers investigated feeding behaviour of pigs based on records from electronic feeding stations (DE HAER and MERKS, 1992; DE HAER and DE VRIES, 1993; YOUNG and LAWRENCE, 1994; FELDE, 1996; HYUN et al., 1997; HALL et al., 1999a; HALL et al. 1999b; SCHULZE, 2001). Generally, the absolute values for feed intake traits vary largely between different studies, because feeding behaviour is influenced by many factors like genotype, sex, live weight range, pen design, stocking density, group size, feed form and environmental conditions (HYUN et al., 1997).

HALL et al. (1999a) investigated genetic and phenotypic parameters for feeding pattern and performance test traits in Large White pigs. They state that feeding patterns may be changed substantially by selection. Genetic correlations with performance test traits indicate that feeding pattern traits can be usefully incorporated in selection criteria to improve somewhat the accuracy of selection. HUISMAN and ARENDONK (2004) conclude that changes in feed intake patterns through selection are possible.

The aim of this study was to compare feed intake behaviour of the two main breeds used as dam lines in Austria, Large White and Landrace, and to clarify whether there is an effect of MHS-type on feeding patterns in Pietrain used as terminal sire line.

\section{Material and Methods}

2.1. Data

Austrian pork production is based on crossbreeding programmes with Large White and Landrace as dam breeds and Pietrain as sire breed. Purebred pigs are tested for growth and carcass traits centrally at one performance test station. The performance test is carried out with male castrates in Large White and Landrace and with females of Pietrain. Piglets are brought to the test station with an average live weight of 6 to $12 \mathrm{~kg}$ and kept in groups of variable size. The performance testing starts at a $30 \mathrm{~kg}$ live weight. The pigs are divided into groups of 10 to 13 and kept in group pens. Each pen is equipped with an electronic feeding station. During the testing period Large White and Landrace animals are kept in mixed groups (with varying composition) while Pietrain is tested separately. The trial ends with a live weight of $106 \mathrm{~kg}$ for Large White and Landrace and $110 \mathrm{~kg}$ in case of Pietrain. Animals reach those live weights after roughly 90 days of test. A standard pelleted growers feed was used, each kilogram containing $13.3 \mathrm{MJ}$ of digestible energy, $18.2 \%$ crude protein, $6.1 \%$ crude fat and $4.2 \%$ crude fibre.

Feed intake behaviour of 1,593 pigs of three different breeds (618 Large White, 486 Landrace, and 489 Pietrain) recorded between May 2001 and May 2002 was analyzed. A total of 3'668,788 visits to the electronic feeding station were registered. When a pig 
visited the feeding station it was identified by its transponder tag, entry and exit times and the amount of feed consumed were logged by a control box and subsequently transferred to a personal computer. Records of this type were generated continuously by individual pigs.

Data were prepared and analysed with the statistical programme package SAS (1999). Thirty three records were excluded due to an impossible (negative) feeder occupation time per visit. Furthermore, visits with less than $3 \mathrm{~g}$ feed intake were not considered. After this first preparation of behaviour data 3'502,523 records were left for further analysis: 1'735,960 for Large White, 865,237 for Landrace and 901,326 for Pietrain. Based on these records the following feed intake behaviour traits were generated:

1) Number of visits in the feeding station per hour (NVF-H) and per test day (NVFTD),

2) Time in the feeding station per hour (TF-H) and per test day (TF-TD),

3) Feed intake per hour (FI-H) and per test day (FI-TD) and

4) Consumption rate in $\mathrm{g} / \mathrm{min}$ per hour (CR-H) and per test day (CR-TD).

Routine recording of fattening and slaughter performance including the following traits: daily gain (DG), feed conversion ratio (FC), lean meat content (LMC, defined as the weight of ham, loin and neck without fat layer in proportion to carcass weight), meat quality index (MQ) and intramuscular fat content (IMF). The meat quality index consists of $\mathrm{pH}$ value, meat colour and drip loss. The relative weights of the index traits are derived via canonical discriminant analysis (TONNER, 1991). For a more detailed description of slaughter performance traits investigated see KNAPP et al., 1997.

\section{2. $\quad$ Models}

Generalized linear models were defined to investigate the feed intake behaviour. For multiple comparisons between breeds the Tukey test (KAPS and LAMBERSON, 2004) was used in models 1 and 2 .

\section{Model 1: Feed Intake Behaviour during a Test Day - 24 Hour Profile}

Model 1 was used to investigate factors influencing the NVF-H, TF-H, FI-H and CR$\mathrm{H}$ (g/min). Hour (24 hours), test day period (test days were merged into units of 5 days, resulting in 23 test day periods), season (defined as three month intervals) and breed were included as fixed effects. In addition all two-way interactions between these effects were tested.

\section{Model 2: Feed Intake Behaviour during Testing Period - 112 Day Profile}

Model 2 serves to describe the feed intake behaviour of growing pigs during the testing period (NVF-TD, TF-TD, FI-TD, CR-TD). The fixed effects of test day (112 test days), season and breed were tested. Again all two-way interactions between main effects were included.

The maximum length of testing period was restricted to 112 days. A low number of animals (2 Landrace and 31 Pietrain pigs) reached the aimed live weight slightly after 112 days. Therefore 139 test day records (8 Landrace and 131 Pietrain) were excluded from the analysis.

\section{Model 3: Effect of the MHS type in Pietrain}

With this model the influence of the MHS type in Pietrain pigs on feed intake behaviour over the testing period was investigated. For this analysis data on the MHS 
genotype of each animal were available coded as PP, NP, NN (results of MHS test) and $\mathrm{PP}^{*}, \mathrm{NP}^{*}$ and $\mathrm{NN}^{*}$ (inferred from MHS genotype of parents). Due to low frequencies for some genotypes (PP*: $0, \mathrm{NN}: 4$ and $\left.\mathrm{NN}^{*}: 11\right)$ two MHS types were built describing animals as stress susceptible (PP) or stress resistant (NP, NP*, NN, $\mathrm{NN}^{*}$ ). Records of 488 animals were used for this analysis, 220 animals were classified as stress susceptible and 268 as stress resistant. This model is similar to model 2. MHS type replaces the breed effect.

\section{Model 4: Relationship between Feed Intake and Growth and Carcass Traits}

Selected growth and carcass traits (DG, FC, LMC, MQ, IMF) are considered as dependent variables and, alternatively, one average daily feed intake behaviour trait (FI, TF, CR) as independent covariable. Linear and quadratic regression coefficients were tested, together with the fixed effect of test day period (see model 1). Analysis was carried out separately for the three breeds.

Model and results for monthly profiles are not published, because data from only 13 months were available, which do not allow a general statement about seasonal effects.

\section{Results}

3.1. $\quad$ Feed Intake Behaviour during Test Day - 24 Hour Profile

The test of the global hypothesis with regard to influence of breed on feed intake behaviour showed a large breed effect on all behaviour traits investigated $(\mathrm{P}<0.0001)$. Large White animals showed the highest activity with 1.28 visits of the feeding station per hour, followed by Landrace with 0.88 and Pietrain with 0.78 . One has to be aware that the "breed" effect can not be disentangled from the sex effect due to the special testing situation. A direct comparison is permissible between the two dam lines only. However, multiple comparisons between breeds revealed highly significant differences between Landrace and Large White $(\mathrm{P}<0.001)$ for all feed intake traits. Landrace animals spent more time per hour in the feeding station and consumed more feed per hour than Large White and Pietrain. An overview on all traits is given in Table 1.

Table 1

Least squares means for number of visits in the feeding station per hour (NVF-H), time in the feeding station per hour (TF-H), feed intake per hour (FI-H) and consumption rate per hour (CR-H) for the breeds Large White (LW), Landrace (LR) and Pietrain (Pit) and standard deviation of residuals (SE) (LS Mittelwerte für Anzahl Besuche in der Fütterungsstation (NVF-H), Verweildauer in der Station (TF-H), Futteraufnahme(FI-H) und Verzehrsrate (CR-H) jeweils pro Stunde für Edelschwein (LW), Landrasse (LR) und Pietrain (Pit), sowie Standardabweichung der Residuen (SE))

\begin{tabular}{lcccc}
\hline trait & LW & LR & Pit & SE \\
\hline NVF-H & 1.28 & 0.88 & 0.78 & 1.99 \\
TF-H (min) & 2.56 & 2.74 & 2.37 & 4.81 \\
FI-H (g) & 95 & 98 & 72 & 165 \\
CR-H (g/min) & 37.0 & 35.7 & 29.9 & 9.2 \\
\hline
\end{tabular}

Figures 1 to 4 show the 24 hour profiles for the behaviour traits. All two-way interactions were highly significant $(\mathrm{P}<0.0001)$ for all observed feed intake behaviour traits. The activity pattern with two peaks during a testing day with maxima between 1 p.m. and 5 p.m. was characteristic for all traits investigated apart from the consumption rate which was more or less independent of the hour. 


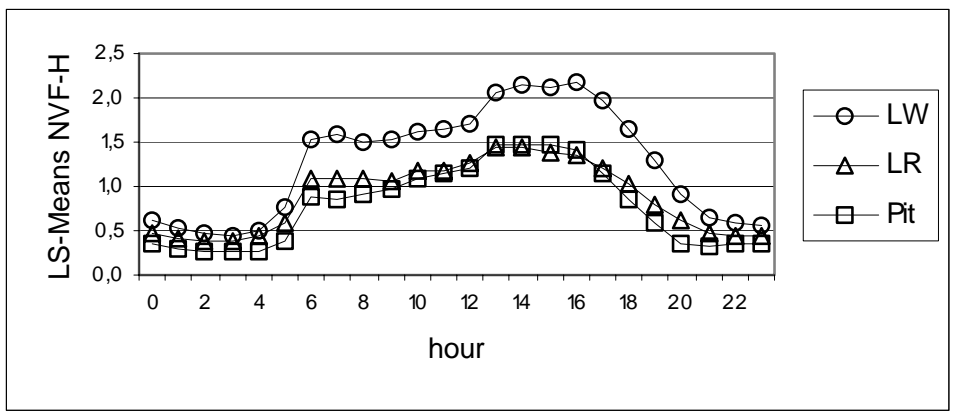

Fig. 1: 24 hour profile for number of visits in the feeding station per hour (NVF-H) for Large White (LW), Landrace (LR) and Pietrain (Pit) (24 Stunden-Profil für Anzahl Besuche in der Fütterungsstation (NVF-H) für Edelschwein (LW), Landrasse (LR) und Pietrain (Pit))

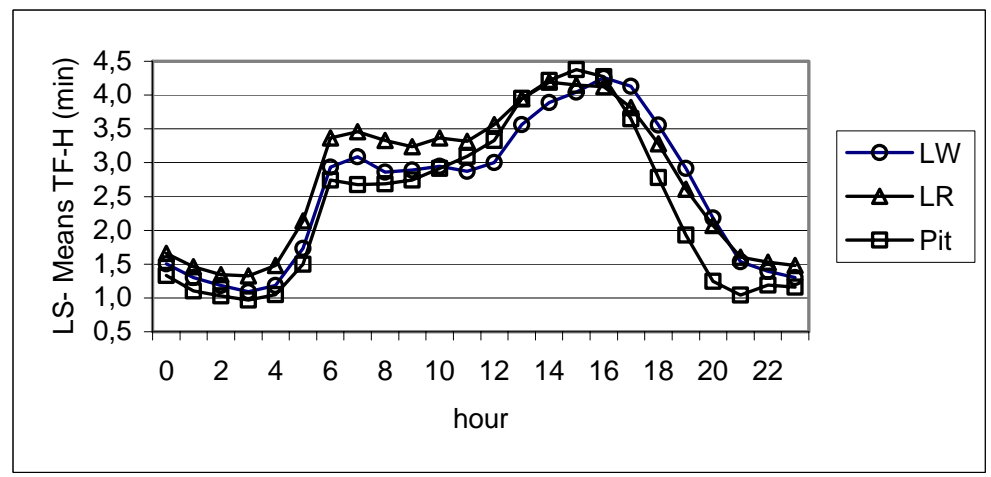

Fig. 2: 24 hour profile for time in the feeding station per hour (TF-H) for Large White (LW), Landrace (LR) and Pietrain (Pit) (24 Stunden-Profil für Verweildauer in der Fütterungsstation (TF-H) für Edelschwein (LW), Landrasse (LR) und Pietrain (Pit))

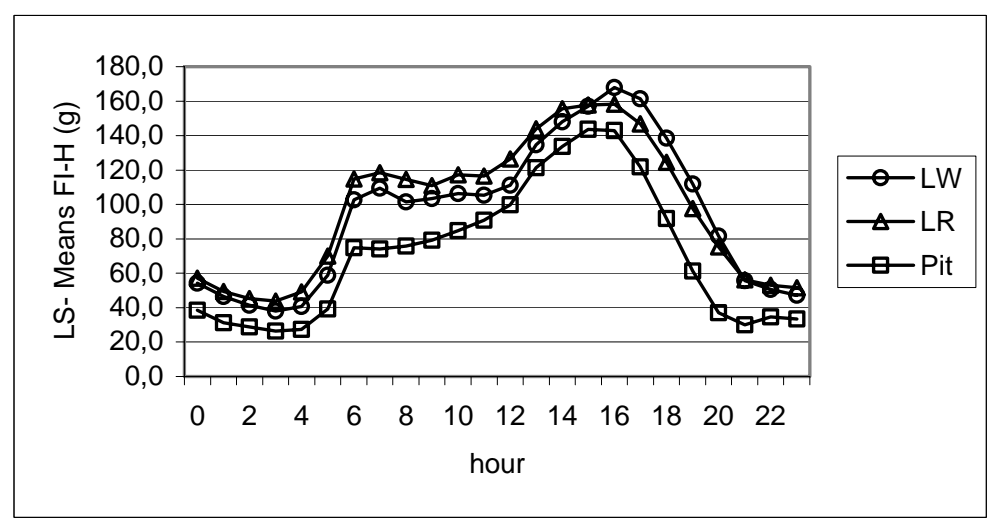

Fig. 3: 24 hour profile for feed intake per hour (FI-H) for Large White (LW), Landrace (LR) and Pietrain (Pit) (24 Stunden-Profil für Futteraufnahme (FI-H) für Edelschwein (LW), Landrasse (LR) und Pietrain (Pit)) 


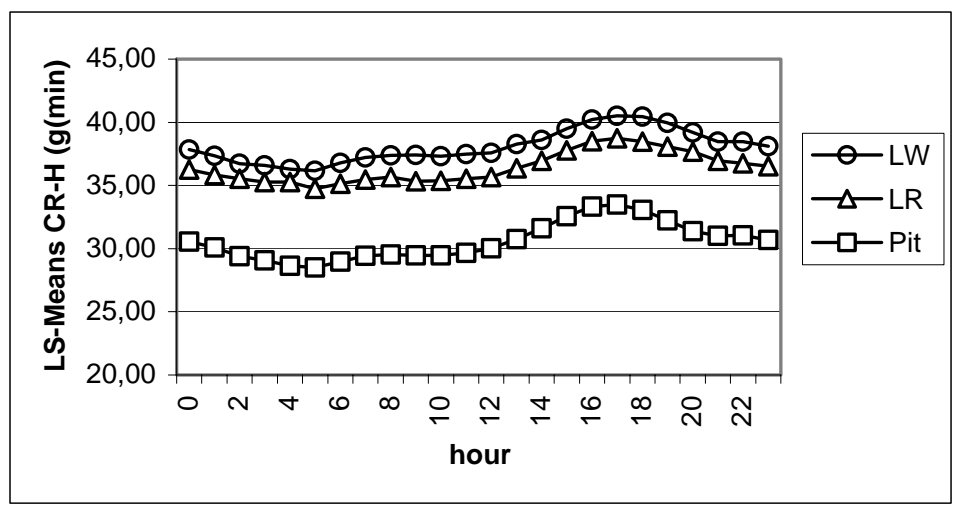

Fig. 4: 24 hour profile for consumption rate (CR-H) in g/min for Large White (LW), Landrace (LR) and Pietrain (Pit) (24 Stunden-Profil für Verweildauer in der Fütterungsstation (CR-H) für Edelschwein (LW), Landrasse (LR) und Pietrain (Pit))

\section{2. $\quad$ Feed Intake Behaviour during Testing Period - 112 Day Profile}

The average length of the whole testing period from $30 \mathrm{~kg}$ live weight up to 106 or $110 \mathrm{~kg}$ differed between the breeds (88 days in Large White, 90 in Landrace and 99 in Pietrain).

A clear difference between all breeds $(\mathrm{P}<0.0001)$ was detected for all feed intake traits investigated (Table 2). Multiple comparisons between breeds revealed also highly significant differences between Large White and Landrace $(\mathrm{P}<0.001)$. Landrace animals showed the highest time in feeding station and the highest feed intake per test day followed by Large White and Pietrain. The amount of feed consumed per day is highly influenced by age and live weight of the animals. Therefore comparisons with literature are of limited value. Large White showed the highest feed intake per minute. Landrace animals have a similar consumption rate. With regard to the number of visits in the feeding station per day Large White is again the most active breed. Large White animals visited the feeding station 30 percent more often than Landrace animals. The two-way interactions between main effects were significant for all traits investigated with this model $(\mathrm{P}<0.0001)$.

Table 2

Least squares means for number of visits in the feeding station per test day (NVF-TD), time in the feeding station per test day (TF-TD), feed intake per test day (FI-TD) and consumption rate (CR-TD) for the breeds Large White (LW), Landrace (LR) and Pietrain (Pit) and standard deviation of residuals (SE) (LS Mittelwerte für Anzahl Besuche in der Fütterungsstation (NVF-TD), Verweildauer in der Station (TF-TD), Futteraufnahme (FI-TD) und Verzehrsrate (CR-TD) pro Tag für Edelschwein (LW), Landrasse (LR) und Pietrain (Pit), sowie Standardabweichung der Residuen (SE))

\begin{tabular}{lcccc}
\hline trait & LW & LR & Pit & SE \\
\hline NVF-TD & 31.0 & 21.0 & 18.6 & 13.8 \\
TF-TD (min) & 62.25 & 66.1 & 57.4 & 16.3 \\
FI-TD (g) & 2,293 & 2,349 & 1,721 & 430 \\
CR-TD (g/min) & 39.4 & 37.5 & 31.9 & 7.5 \\
\hline
\end{tabular}

The feed intake profiles for the testing period (Figure 5) showed a relatively constant number of visits in the feeding station per day during the whole testing period. Only Landrace animals increased the number of visits during the last third of the period. Further, Figure 5 shows the higher activity of Large White pigs compared to Landrace, but due to the longer occupation time in the feeding station of Landrace animals (Figure 6) both dam lines consume a similar amount of feed per day (Figure 7). A 
decrease in the average time per day spent in the feeding station linked with an increase in the daily total amount of feed intake was observed for all breeds. This discrepancy can be explained by the increasing consumption rate (Figures 6-8).

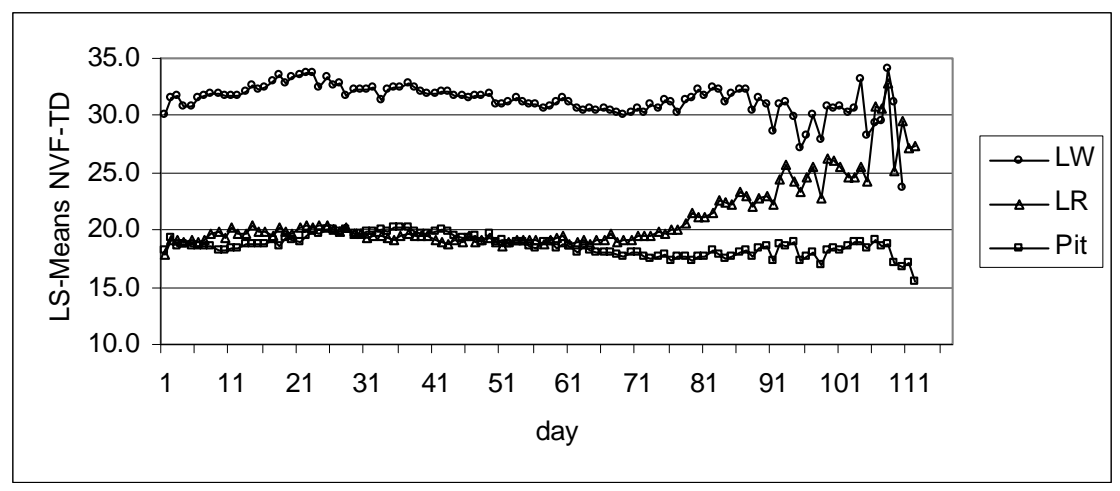

Fig. 5: 112 test day profile for number of visits in the feeding station per test day (NVF-TD) for Large White (LW), Landrace (LR) and Pietrain (Pit) (112 Tage-Profil für Anzahl Besuche in der Fütterungsstation (NVF-TD) für Edelschwein (LW), Landrasse (LR) und Pietrain (Pit))

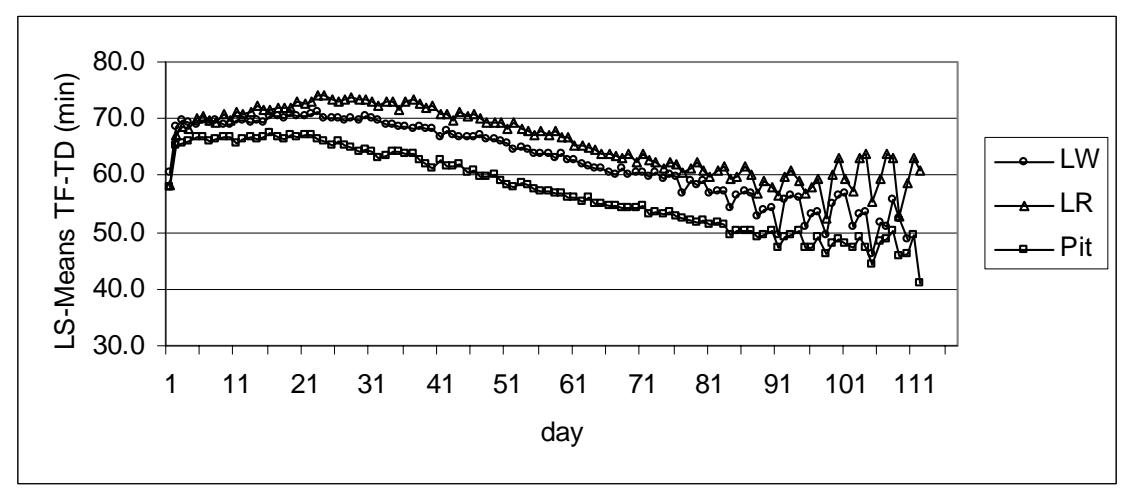

Fig. 6: 112 test day profile for time in the feeding station per test day (TF-TD) for Large White (LW), Landrace (LR) and Pietrain (Pit) (112 Tage-Profil für Verweildauer in der Fütterungsstation (TF-TD) für Edelschwein (LW), Landrasse (LR) und Pietrain (Pit))

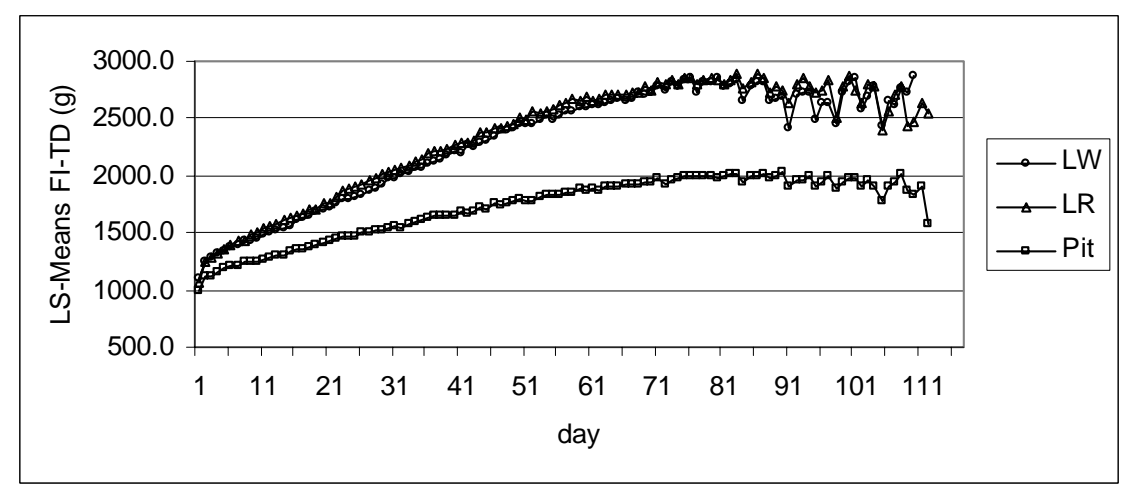

Fig. 7: 112 test day profile for feed intake per test day (FI-TD) for Large White (LW), Landrace (LR) and Pietrain (Pit) (112 Tage-Profil für Futteraufnahme (FI-TD) für Edelschwein (LW), Landrasse (LR) und Pietrain (Pit)) 


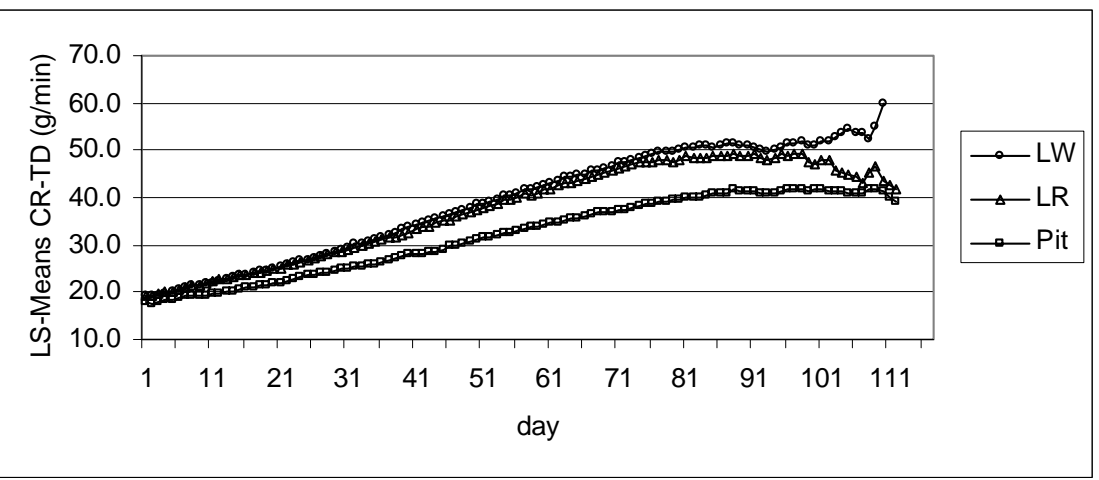

Fig. 8: 112 test day profile for consumption rate per test day (CR-TD) in g/min for Large White (LW), Landrace (LR) and Pietrain (Pit) (112 Tage-Profil für Verzehrsrate (CR-TD) für Edelschwein (LW), Landrasse (LR) und Pietrain (Pit))

\subsection{Effect of the MHS type in Pietrain}

For all results above, no distinction was made between MHS types in Pietrain. With exception of time spent in the feeding station per day $(\mathrm{P}=0.6062)$ small but significant $(\mathrm{P}<0.0001)$ differences were detected between stress susceptible and stress resistant Pietrain animals. The average number of visits per test day was higher in stress susceptible animals (Table 3). The higher consumption rate combined with less time spent in the feeding station per testing day resulted in a slightly higher feed intake per day in stress resistant pigs. The interaction between test day and MHS was not significant for any of the traits. Therefore the feed intake profiles were almost identical for the two MHS types (not shown here).

Table 3

Least squares means for feed intake behaviour traits per testing day for the MHS types stress susceptible and stress resistant and standard deviation of residuals (SE) (LS Mittelwerte für Merkmale des Futteraufnahmeverhaltens pro Prüftag für stressresistente und stressstabile MHS Typen, sowie Standardabweichungen der Residuen (SE))

\begin{tabular}{lccc}
\hline trait & $\begin{array}{c}\text { Stress } \\
\text { susceptible }\end{array}$ & $\begin{array}{c}\text { Stress } \\
\text { resistant }\end{array}$ & SE \\
\hline Number of visits in the feeding station & 19.3 & 18.0 & 9.5 \\
Time in the feeding station (min) & 57.5 & 57.4 & 14.2 \\
Feed intake (g) & 1,710 & 1,731 & 326 \\
Consumption rate (g/min) & 31.7 & 32.0 & 6.3 \\
\hline
\end{tabular}

\subsection{Relationship between Feed Intake and Growth and Carcass Traits}

Table 4 shows arithmetic means for the average daily feed intake, time spent in the feeding station and some growth and carcass traits. Table 5 comprises the results for linear and quadratic regression coefficients. The units of the considered traits are described in Table 5. Not surprisingly increased feed intake had a positive effect on daily gain in all three breeds, a slightly negative effect on lean meat content and a positive effect on intramuscular fat content in all three breeds. In the study in hand 47\% (Large White), 42\% (Landrace) and 60\% (Pietrain) of variation in daily gain could be explained by variation of feed intake. For the average time spent in the feeding station the relationships with performance were heterogeneous for the three breeds. The average consumption rate seems not to influence the majority of carcass traits in any breed. 
Table 4

Arithmetic mean (mean) and standard deviation (s) for feed intake behaviour traits per testing day and growth and carcass traits (Mittelwerte (mean) und Standardabweichungen (s) für Merkmale des Futteraufnahmeverhaltens pro Prüftag, sowie für Merkmale der Mast- und Schlachtleistung)

\begin{tabular}{lcccccc}
\hline \multirow{2}{*}{ trait } & \multicolumn{2}{c}{ Large White } & \multicolumn{2}{c}{ Landrace } & \multicolumn{2}{c}{ Pietrain } \\
\cline { 2 - 7 } & mean & $\mathrm{s}$ & mean & $\mathrm{s}$ & mean & $\mathrm{s}$ \\
\hline Daily gain (g) & 869 & 81.75 & 854 & 79.24 & 714 & 72.00 \\
Feed conversion (kg/kg) & 2.57 & 0.18 & 2.68 & 0.22 & 2.40 & 0.17 \\
Lean meat content (\%) & 47.7 & 1.82 & 47.6 & 2.23 & 55.6 & 1.57 \\
Meat quality index (points) & 109.8 & 4.96 & 109.2 & 5.54 & 95.9 & 13.47 \\
Intramuscular fat content (\%) & 1.02 & 0.42 & 0.97 & 0.43 & 0.63 & 0.28 \\
\hline Feed intake(g) & 2,214 & 185 & 2,277 & 196 & 1,704 & 139 \\
Time in the feeding station (min) & 65.2 & 12.2 & 67.9 & 12.21 & 58.90 & 10.2 \\
Consumption rate (g/min) & 35.9 & 6.48 & 35.3 & 6.51 & 30.7 & 5.20 \\
\hline
\end{tabular}

Table 5

Linear and quadratic (italic) regression coefficients of daily gain (DG), feed conversion (FC), lean meat content (LMC), meat quality index (MQ) and intramuscular fat content (IMF) on average feed intake per day, average time spent in the feeding station per day and average consumption rate per day in Large White (LW), Landrace (LR) and Pietrain (Pit). Regression coefficients given for $\mathrm{P}<0.01$, ns for non significant results (Lineare und quadratische (kursiv) Regressionskoeffizienten für die tägliche Zunahme (DG), Futterverwertung (FC), Magerfleischanteil (LMC), Fleischbeschaffenheitszahl (MQ) und intramuskulären Fettgehalt (IMF) auf die durchschnittliche tägliche Futteraufnahme, Verweildauer in der Station und auf Futterverzehrsrate für Edelschwein (LW), Landrasse (LR) und Pietrain (Pit). Regressionskoeffizienten für $\mathrm{P}<0.01$, angegeben, für nicht signifikante Resultate steht ns)

\begin{tabular}{|c|c|c|c|c|c|c|c|c|c|}
\hline \multirow[b]{2}{*}{ Trait } & \multicolumn{3}{|c|}{ Feed intake } & \multicolumn{3}{|c|}{ Time in feeding station } & \multicolumn{3}{|c|}{ Consumption rate } \\
\hline & LW & LR & Pit & LW & LR & Pit & LW & LR & Pit \\
\hline$\overline{D G}$ & 0.2947 & 0.2372 & 0.3970 & $\begin{array}{c}7.0412 \\
-.0394\end{array}$ & ns & 2.0165 & ns & 2.2385 & ns \\
\hline FC & 0.0003 & 0.0004 & ns & ns & ns & -0.0029 & 0.0048 & ns & 0.0066 \\
\hline LMC & -0.0050 & -0.0062 & $\begin{array}{c}0.0210 \\
-.000008\end{array}$ & -0.0215 & $\begin{array}{c}-0.1950 \\
.0012\end{array}$ & ns & ns & ns & ns \\
\hline MQ & ns & ns & ns & ns & -0.0637 & ns & ns & 0.1009 & ns \\
\hline IMF & 0.0005 & 0.0004 & 0.0006 & ns & ns & ns & ns & ns & ns \\
\hline
\end{tabular}

\section{Discussion}

DE HAER and DE VRIES (1993) and HYUN and ELLIS (2002) found similar values for consumption rate for a 24 hour profile. Values from the 112 day profile are in agreement with observations by DE HAER and DE VRIES (1993), who investigated Belgian Landrace and Great Yorkshire pigs. The literature provides examples for both, single peaked (YOUNG and LAWRENCE, 1994; HYUN et al., 1997) and more often two peaked (MONTGOMERY et al., 1978; SCHOUTEN, 1986; FEDDES et al., 1989; DE HAER and MERKS, 1992; AUGSPURGER et al., 2002) activity patterns. In this study light was switched on in the stables automatically at 6 a.m. which might be one explanation for the first activity peak; FEDDES, YOUNG and DESHAZER (1989) showed the influence of the light period on diurnal activity patterning in pigs.

The behaviour patterns over 24 hours and the testing period of 112 days gave insight in characteristic patterns of feed intake behaviour of pigs housed in group pens. Large White animals showed the highest activity during a single test day and over the testing period. However the average time spent in the feeding station per hour and per testing day as well as average feed intake per hour and testing day was highest in Landrace. The feed intake strategy of Large White animals can be characterized by a high number of visits in the feeding station combined with shorter time spent in the feeding 
station and a lower amount of feed consumed per meal. Landrace animals follow a different strategy: The lower number of visits per hour is compensated with staying longer in the feeding station and higher feed intake per visit. Pietrain animals show the lowest results in all behaviour traits. This is related to the lower feed intake of that breed. Whether Landrace and Large White pigs developed different feed intake strategies because they are kept in mixed groups or the same differences would have been observed separating Large White and Landrace groups may not be answered by this study. No additional observation on other aspects of behaviour was carried out. Therefore it is not possible to make reliable statements about social interaction and competition for feed of animals in mixed groups.

A differentiation between the MHS types in Pietrain is also interesting with regard to the Austrian Pietrain breeding programme, where establishing homozygous stress resistant Pietrain lines is aimed at. The effect of MHS type on several performance traits is investigated in many studies (e.g. KUSEK et al., 2005; GLODEK et al., 2004; BIEDERMANN et al., 2000; THALLER et al., 2000), but not on feed intake behaviour traits as in this study. The effect of MHS type on feed intake behaviour in Pietrain is low. The small significant differences are of marginal relevance for a practical breeding strategy.

The relationships between performance traits and selected feed intake behaviour traits are quite heterogeneous for the three investigated pig breeds. Only with regard to average feed intake per day the trends were relatively uniform. A study of YOUNG and LAWRENCE (1994) emphasizes the importance of the trait feed intake with regard to performance traits. The authors found that $59 \%$ of the variance of the trait daily gain may be explained by variance of feed intake. HALL et al. (1999a) found a heritability of 0.21 for daily feed intake and weak genetic correlation between feed intake and other behaviour traits like time in the feeding station and consumption rate but high genetic correlations with performance test traits (backfat depth, food conversion ratio and average daily gain). HUISMAN and ARENDONK (2004) estimate heritability for daily fee intake at different days on test of Dutch Landrace gilts. The heritability decreased from 0.53 at 5 days on test to 0.24 at 95 days on test. They conclude that changes in feed intake patterns through selection are possible. HALL et al. (1999b) suggest including daily feed intake and the mean number of visits in the feeding station per day as selection criteria. Average feed intake might be the most promising candidate to be included into a selection index with regard to literature and results shown here. Records of feed intake behaviour might serve to control whether selection on growth and carcass traits leads to changes in feeding patterns.

Large White and Landrace animals show clearly different feed intake patterns, but Landrace animals compensate a lower number of visits in the feeding station with more time spent in the station and higher consumption rate. Therefore Large White and Landrace end up with similar feed intake. This result does not suggest changing the current practice, where both breeds are kept together in group pens during performance testing.

The MHS type of Pietrain pigs does not severely influence feeding patterns. Therefore there is no urgent need to consider feed intake behaviour traits in breeding programmes for Pietrain. Nevertheless incorporating traits like average daily feed intake in the selection indices for pigs might result in an improved accuracy of selection. 


\section{Acknowledgements}

The authors thank Christian Draxl from the performance test station "Österreichische Schweineprüfanstalt GmbH” for providing data for this study.

\section{References}

AUGSPURGER, N. R.; ELLIS, M.; HAMILTON, D. N.; WOLTER, B. F., BEVERLY, J. L.; WILSON., E. R.: The effect of sire line on the feeding patterns of grow-finish pigs. Appl. Anim. Behav. Sci. 75 (2002), 103-114

BIEDERMANN, G.; JATSCH, CH.; PESCHKE, W.; LINDNER, J.-P.; WITTMANN, W.:

Mast- und Schlachtleistung sowie Fleisch- und Fettqualität von Pietrain-Schweinen unterschiedlichen MHS-Genotyps und Geschlechts. I. Mitt.: Mast- und Schlachtleistung sowie Fleischqualität. Arch. Tierz., Dummerstorf 43 (2000) 2, 151-164

DE HAER, L. C. M.; MERKS; J. W. M.:

Patterns of daily feed intake in growing pigs. Anim. Prod. 54 (1992), 95-104

DE HAER, L. C. M.; DE VRIES, A. G.:

Effects of genotype and sex on the feed intake pattern of group-housed growing pigs. Livest. Prod. Sci. 36 (1993), 223-232

FEDDES, J.J.R.; YOUNG, B.A.; DESHAZER, J. A.:

Influence of temperature and light on feeding behaviour of pigs. Appl. Anim. Behav. Sci. 23 (1989), 215-222

FELDE, A. v.:

Genetische Analyse der Futteraufnahme-Information von Jungebern aus Gruppenprüfung mit automatischen Fütterungsanlagen. Dissertation, Schriftenreihe des Institutes für Tierzucht und Tierhaltung der Christian-Albrechts-Universität zu Kiel, Heft 90 (1996)

GLODEK, P.; KRATZ, R.; SCHULZ, E.; FLACHOWSKY, G.:

Effect of sire breeds in commercial pig crosses on growth, carcass composition, meat and fat quality. Arch. Tierz., Dummerstorf 47 (2004), 59-74

HALL, A. D.; HILL, W. G.; BAMPTON, P. R.; WEBB; A. J.:

Genetic and phenotypic parameter estimates for feeding pattern and performance test traits in pigs. Anim. Sci. 68 (1999a), 43-48

HALL, A. D.; HILL, W. G.; BAMPTON, P. R.; WEBB, A. J.:

Predicted responses to selection from indices incorporating feeding pattern traits of pigs using electronic feeders. Anim. Sci. 68 (1999b), 407-412

HUISMAN, A. E.; VAN ARENDONK, J. A. M:

Genetic Parameters for daily feed intake patterns of growing Dutch Landrace gilts. Livest. Prod. Sci. 87 (2004), 221-228

HYUN, Y; ELLIS M.; MCKEITH, F. K.; WILSON, E. R.:

Feed intake pattern of group-housed growing-finishing pigs monitored using a computerized feed intake recording system. J. Anim. Sci. 75 (1997), 1443-1451

HYUN, Y.; ELLIS, M.:

Effect of group size and feeder type on growth performance and feeding patterns in finishing pigs. J. Anim. Sci. 80 (2002), 568-574

KAPS, M.; LAMBERSON, W. Biostatistics for Animal Science. Cromwell Press, Trowbridge, UK (2004)

KNAPP, P.; WILLAM, A.; SÖLKNER, J.:

Genetic parameters for lean meat content and meat quality traits in different pig breeds. Livest. Prod. Sci. 52 (1997), 69-73

KUSEK, G.; BAULAIN, U.; HENNING, M.; KÖHLER, P.; KALLWEIT, E.:

Fattening, carcass and meat quality traits of hybrid pigs as influenced by MHS genotype and feeding system. Arch. Tierz., Dummerstorf 48 (2005) 1, 40-49

MONTGOMERY, G. W.; FLUX, D. S.; CARR, J. R:

Feeding patterns in pigs: The effects of amino acid deficiency. Physiology and behaviour 20 (1978), 693-698

SAS:

Software. Release 8.0 SAS Institute Inc., Cary NC, USA 27513 (1999)

SCHOUTEN, W.G.P.:

Rearing conditions and behaviour in pigs. Ph.D. Thesis, University of Wageningen (1986) 
SCHULZE, V.:

Genetische Analysen zur Optimierung des Verlaufes der individuellen Futteraufnahme und Tageszunahme während der Wachstumsperiode beim Schwein. Dissertation, Schriftenreihe des Institutes für Tierzucht und Tierhaltung der Christian-Albrechts-Universität zu Kiel, Heft 122 (2001)

THALLER, G.; DEMPFLE, L.; SCHLECHT, A.; WIEDEMANN, S.; EICHINGER, H.; FRIES, R.:

Effects of the MHS locus on growth, carcass and meat quality traits in $F_{2}$ crosses between Mangalitza and Pietrain breeds. Arch. Tierz., Dummerstorf 43 (2000) 3, 263-275

TONNER, F.:

Schätzung von Gewichtungsfaktoren für Einzelmerkmale der Fleischbeschaffenheitszahl mittels Diskriminanzanalyse. Diplomarbeit, Institut für Nutztierwissenschaften der Universität für Bodenkultur Wien (1991)

WEBB, A. J.; BRAMPTON, P. R.; SMITH, S.; CLOSE, S. P.:

Electronics in genetic improvements of pigs. Animal Production 50 (1990), 576

YOUNG, R.J.:

Factors affecting foraging motivation in the domestc pig. PHD-Thesis, Institute of Ecology and Resource Management, University of Edinburgh (1993)

YOUNG, R. J.; LAWRENCE, A. B.:

Feeding behaviour of pigs in groups monitored by a computerized feeding system. Anim. Prod. 58 (1994), 145-152

Received: 2005-06-24

Accepted: 2005-12-12

Corresponding author

Dr. ROSWITHA BAUMUNG

University of Natural Resources and Applied Life Sciences Vienna

Division of Livestock Sciences

Gregor Mendel-Str. 33

A-1180 Vienna

Austria

E-mail: roswitha.baumung@boku.ac.at 